\title{
The Impact of Literacy on Vocational Skills Acquisition for Better Community Participation
}

\author{
Adedokun, Mary Olufunke \\ Faculty of Education \\ Ekiti State University, Ado Ekiti \\ Tel: +234-80-34806200Ｅ-mail: funkadedokun@yahoo.com \\ Oluwagbohumni, Margaret Foluke \\ Faculty of Education \\ Ekiti State University, Ado Ekiti \\ Tel: $+234-80-69525982$ \\ E-mail:drmagfol@yahoo.com
}

Received: 10-08- 2013

doi:10.7575/aiac.ijels.v.1n.2p.12
Accepted: 27-09-2013

Published: $31-10-2013$

\begin{abstract}
This study examined the impact of literacy on vocational skill acquisition with the aim of making the young people self- reliant, thereby helping them to be more involved in community participation and participate more in community issues. In this study, vocational skill acquisition is used synonymously with apprenticeship scheme. Two local government areas in Oyo state were used for the study with 200 subjects as sample. Three hypotheses were generated for the study and data were collected through a self designed questionnaire tagged "Literacy for vocational skill Acquisition" (LVSA). The collected data were analyzed using t-test statistical tool at 0.05 level of significance. The result showed that literacy has a lot of impact on skill acquisition. That being literate would make a person stand tall among equals in vocational skill acquisition and later practice. That literacy would make a person not only functional in the sense of being permanent for application in daily context but in the sense of being adaptable to new and changing circumstances and requirements in their job performance. That there is a significant relationship between literacy and skill acquisition as those who were literate caught up better than those who were not literate and they performed their jobs better than the illiterate ones. The study recommended among others that for people to be really self reliant in the daily performance of their jobs, they must be literate as it is through literacy that necessary information can be gathered for better job performance in the communities.
\end{abstract}

Keywords: self reliance, information literacy, adult education, development, apprentice

\section{Introduction}

Literacy is critical to the development of individual Nigerians and the country. The Independent Commission on population and quality of Life (ICPQL, 1996) graphically highlights the limitations of the illiterate. In the present day society in which everything - law, rules, instructional directions are written, illiteracy is a severe handicap when participating in decision that affects affecting life: it is tantamount to disability, affecting every aspect of living. It confines job opportunities to the most medial and low paid tasks (ICPQL, 1996). The above implies that when people are not literate, their participation in national discourse and in social and economic transactions is hardly significant or meaningful (Nnazor, 2005). Nigeria as a country must not only concentrate its educational investment in youth and formal education alone but must keep with the philosophy of lifelong. Learning which is what adult education stands for and of which literacy education is an integral part. (lalomen Whitch, 2005).

UNESCO defines literacy as the ability to identify, understand, interpret, create, communicate and compute using printed and written materials associated with varying contests (UNESCO in Ogitso Olomukoro, 2010). Literacy therefore involves a continuum of learning to enable an individual to achieve his or her goals, to develop her knowledge and to participate fully in the community in which he or she lives. This therefore means literacy is a powerful tool in empowering artisans and others in thanking communities to perform their functions very appreciably in the community.

Ogisto and Olomukoro 2010 see literacy as an indispensable means for effective, social and economic participation contributing to human development and poverty reduction. Literacy empowers and contributes to the fair implementation of human rights. Literacy therefore must address the needs of everybody within the society and it should be in line with the goals of economic, social and cultural development of all people in every community (UNESCO 2005). Bhola (1983) in Sarumi (2005) feels strongly that development without literacy lumps only on one 
leg as it cannot turn out to be an all round development. Literacy is therefore a viable tool for all forms of development efforts and a strong tool for poverty alleviation.

Literacy is a sine qua non for the social, economic, cultural and political emancipation of everybody and so it should be functional and not limited to reading, writing and arithmetic. The impact of literacy should be felt in vocational skills embarked upon mailing the artisans to relate literacy to their skill with a focus on enabling them to get involved in community participation in the wider community. This means that literacy should bring people to an awareness of their condition and to the democratic rights, which will eventually enable them to participate in making decisions regarding their social, economic and political problems as well as the problems of their existence.

Vocational skills acquired in training centres or through apprenticeship schemes need literate persons for success to be recorded; going by the Nigerian Policy of Education, education should be for self reliance (FRN, 2004). It, therefore, means everyone must be opened to a process of information acquisition in order to access valuable information without being literate. As Okerulu (2003) states, information technology (IT) has recreated limitless opportunities for open access to information. This call for the development of information literacy skills as those skills, according to Julian (2002), will enable users to make efficient and effective use of information sources.

Information literacy (which the researcher is using literarily here to mean ability to search for information that will be of relevance to one's vocational skill is important not only to those in higher institutions of learning but to those in various vocations because an information literate person, according to Wikipedia (information literacy 2007), is one who recognizes that accurate and complete information is the basis for intelligent decision making and he/she is the one that:

- Recognizes the need for information

- Knows how to locate needed information

- Organizes information for practices application

- Uses information in critical thinking and problem solving (Abdulwahab, et-al ).

Everyone in any vocation should have the ability to locate, manage, evaluate and use information for problem solving concerning their areas of vocational specialization. Familumo and Oyelade (2012) state that social thinkers centuries ago were unanimous in their thought that artisans in any society were the monetary of economy. They also corroborated this view further by stating that Plato in his Republic stated that if society must have peace, its ruling class led by the philosopher king must ensure that artisans find right vocations, trained according to their callings and be fitted to it. When people are trained for right vocations and are literate then they can be said to be perfectly fitted to it as they will have the wherewithal of searching for relevant information that will keep them relevant among their colleagues and in relation to the community.

The importance of skill acquisition for personal as well as community development was brought to limelight when the Lagos State Government Nigeria said that apart from the sustained support given to the ordinary people, the government has evolved a people-oriented policy of facilitating training for the young people to acquire skills and grant them access to credit to start their own business. To ensure that the trained people put literacy to use, the government has created a data base for the trained people to relate with themselves through the compilation publication of the Lagos State Business Directory. This move by the Lagos State government calls for information literacy skill on the part of those who are acquiring vocational skill of one sort or another.

Vocational skills acquisition will turn out young men and women with productive skills with which they will put food on thousands of tables and contributing to the economy of the nation while at the same time improving their living standard. For their skills to be put to maximum use and with innovative ideas coming up from time to time to improve their on the job performance, literacy is of paramount importance (BRF forum).

The relevance and utility of vocational skill acquisition lies in the practical application of what they are exposed to. This is why Rogers commented that the economic and social benefits of literacy do not spring from learning skills literacy but from using literacy skills. When literacy skills are applied to vocational practice, the best is what will spring up.

Vocational skill acquisition from this study is approached from the point of view of vocational skill acquisition through apprenticeship scheme as a process of obtaining knowledge of a technical or practical nature from an individual that can impart such knowledge aimed at practical purposes.

The focus of this study therefore is to examine the extent to which literacy will impact on vocational skill acquisition with the aim of making people participate more in community issues.

The following questions are generated for the study.

1. Will literacy affect quick skill acquisition?

2. What is the difference in the rate of skill acquisition between literate apprentice(s) and the illiterate ones?

3. What is the difference in the perceptive of trainees and trainers in the importance of literacy in vocational skill acquisition?

\section{Hypotheses}

Three hypotheses were generated for the study: 
1. Literacy will not significantly impact on vocational skill acquisition.

2. There is no significant difference in the rate of vocational skill acquisition between literate and illiterate trainees.

3. There is no significant difference in the perceptions of trainers and trainees on the importance of literacy in vocational skill acquisition.

\section{Methodology}

The population comprised of all the apprentices in the chosen vocations and their masters in the two local government areas used for the study. Two hundred samples from two local government areas were randomly selected from the population. The instrument for the study was a self designed questionnaire titled "Impact of literacy on vocational skill Acquisition" (ILVSA). The instrument consisted of three sections A, B - comprises items for Q 1 \& 2 and C. Section A was in the Bio data of the samples, Section B was for the apprentices and Section C was for the masters.

The questionnaire had 15 items which was based on the impact of literacy on vocational skill acquisition. The questionnaire was validated by experts in the department of Tests and Measurement and was subjected to test retest for its reliability. A reliability co-efficient of 0.82 was obtained at 0.05 level of significance. The questionnaire items were scored on two -point scale of Yes/No. The data collected for the study were analyzed using frequency counts and percentages for the research questions while the hypotheses were subjected to t-test statistical tool.

\section{Results}

Table 1. Respondents by Sex

\begin{tabular}{ccc}
\hline Sex & Frequency & Percentage \\
\hline Male & 118 & 59 \\
Female & 82 & 41 \\
\hline Total & 200 & 100 \\
\hline
\end{tabular}

Table 1 reveals that 118 males representing 59\% and 82 females representing $41 \%$ were involved in the study.

\section{Research Hypotheses:}

Research Question 1: Will literacy affect quick skill acquisition?

Table 2. Effect of Literacy on skill Acquisition

\begin{tabular}{|c|c|c|c|}
\hline & Qualification of apprentice respondents (190) & Frq. & Percentage \\
\hline 1. & $\begin{array}{l}\text { Literacy is the ability to read, write and do simple } \\
\text { arithmetic }\end{array}$ & 3 & 1.5 \\
\hline 2. & $\begin{array}{l}\text { There is need for literacy in the following vocations: } \\
\text { (a) Fashion designing } \\
\text { (b) Welding } \\
\text { (c) Hair dressing } \\
\text { (d) Catherine services } \\
\text { (e) Repair works, Motor mechanic, radio mechanic etc. }\end{array}$ & $\begin{array}{c}88(94 \%) \\
180(90 \%) \\
150(75 \%) \\
179(89.5 \%) \\
70(35 \%)\end{array}$ & $\begin{array}{l}20(10 \%) \\
50(25 \%) \\
21(10.5 \%) \\
10(9.5 \%) \\
130(65 \%)\end{array}$ \\
\hline 3. & My vocation needs literacy & $180(90 \%)$ & $20 \%$ \\
\hline 4. & I can perform my job better if I am literate & $167(83.5 \%)$ & $33(16.5 \%)$ \\
\hline 5. & $\begin{array}{l}\text { Being literate makes it easy for me to learn quickly and } \\
\text { use my initiative for innovations }\end{array}$ & $191(95.5 \%)$ & $9(4.5 \%)$ \\
\hline
\end{tabular}

Table 2 reveals that $94 \%$ of the respondents believed that literacy involves reading, writing and arithmetic while 180 ; 150, 179, 181 respondents all agreed strongly that literacy is highly valued and needed in the fashion designing, welding, hair dressing, and catering services. However, $130(65 \%)$ disagree to the importance of literacy in repair works. $83.5 \%$ of the respondents affirmed that they would be better on their job performance if they are literate, while 19 (95.5\% respondents believed that being literate makes it easy for them to perform their jobs better than the illiterate ones. 
Research Question 2: What is the rate of skill acquisition between literate apprentices and illiteracy?

\begin{tabular}{|l|l|l|l|}
\hline & Skill & Frq. & Percentage \\
\hline 1. & $\begin{array}{l}\text { The illiterate apprentices are better in catching up in skill } \\
\text { acquisition earlier than the illiterate ones }\end{array}$ & $178(89 \%)$ & $22(11 \%)$ \\
\hline 2. & $\begin{array}{l}\text { The literate apprentices are able to gather information } \\
\text { concerning their vocations from books, newspaper, } \\
\text { magazines and on the interest }\end{array}$ & $191(95.5 \%)$ & $9(4.5 \%)$ \\
\hline 3. & $\begin{array}{l}\text { The literate apprentices are more independent than the } \\
\text { illiterate ones }\end{array}$ & $131(65.5 \%)$ & $69(34.5 \%)$ \\
\hline 4. & $\begin{array}{l}\text { The essence of literacy in apprenticeship scheme is to use } \\
\text { literacy skill to enhance the practicability of their } \\
\text { occasions }\end{array}$ & $195(95 \%)$ & $4(2 \%)$ \\
\hline 5. & $\begin{array}{l}\text { Being literate makes it easy for me to learn quickly and } \\
\text { use my initiative for innovations }\end{array}$ & $191(95.5 \%)$ & $9(4.5 \%)$ \\
\hline
\end{tabular}

Table 3 shows that apprentices that are literate are able to catch up easily in skill acquisition than their illiterate counterparts. 178 respondents affirmed this. 191 (95.5\%) respondents agreed that literate respondents are able to gather information concerning their vocations from books, newspapers, magazines and even on the net as they have access to phone browsing. 196 (98\%) respondents were of the opinion that literacy would enhance the practicability of their vocations.

Research Questions 3: What is the difference in the perceptions of trainers on the importance of literacy on the literate trainees and illiterate ones on vocational skill acquisition?

\begin{tabular}{|l|l|l|l|}
\hline & Skill & Frq. & Percentage \\
\hline 1. & Literacy is a necessary tool for vocational acquisition & $180(90 \%)$ & $20(10 \%)$ \\
\hline 2. & $\begin{array}{l}\text { The literate apprentices understand the nitty-gritty of their } \\
\text { chosen vocations than the illiterate ones. }\end{array}$ & $179(89.5 \%)$ & $21(10.5 \%)$ \\
\hline 3. & Being an illiterate does not retard my job performance & $71(35.5 \%)$ & $129(64.5 \%)$ \\
\hline 4. & $\begin{array}{l}\text { Literacy will help one in the use of one's initiative to bring } \\
\text { better innovations into job performance. }\end{array}$ & $185(92.5 \%)$ & $15(7.5 \%)$ \\
\hline 5. & $\begin{array}{l}\text { Being literate will help an apprentice to master his/her job } \\
\text { quickly and perform it better than the illiterate ones. }\end{array}$ & $182(91 \%)$ & $18(9.0 \%)$ \\
\hline
\end{tabular}

$180(90 \%)$ respondents believed that literacy is a necessary tool for vocational acquisition while 179(89.5\%) respondents believed that the literate apprentices would understand the nitty-gritty of chosen professions than the illiterate ones.

129 (64.5) respondents believed that their not being educated would not retard their job performance while 185 respondents also believed that literacy will help them in the use of their initiatives to bring innovations to their job performance.

Hypothesis 1: Literacy will not significantly impact vocational skill acquisition

Table 5. T-test Summary showing the impact of literacy in vocational Skills Acquisition

\begin{tabular}{llllllll}
\hline & Literacy & $\mathrm{N}$ & Mean & S.D & df & t & Sig. \\
\hline Vocational Skill & Literate & 96 & 26 & 3.62 & & & \\
\cline { 2 - 5 } Acquisition & Illiterate & 104 & 19 & 2.74 & 198 & \multirow{2}{*}{17.25} & $\mathrm{P}<.05$ \\
\hline
\end{tabular}

In table 5, the $\mathrm{t}$-test result shows that literacy had significant impact on vocational skill acquisition at $[\mathrm{t}(198)=17.25 ; \mathrm{P}$ $<.05]$. This implies that the mean score on literacy is 26 while that of illiteracy is 19 which suggest that vocational skill acquisition can be significantly increased with increase in the level of literacy among the apprentices. This result negates the stated null hypothesis and so the hypothesis is rejected in this current study. 
Hypothesis 2: There is no significant difference between the rate of vocational skill acquisition between literate and illiterate trainees.

Table 6. T-test summary showing the rate of skill acquisition among trainees

\begin{tabular}{|c|c|c|c|c|c|c|c|}
\hline & Literacy & $\mathrm{N}$ & Mean & S.D & $\mathrm{df}$ & $\mathrm{t}$ & Sig. \\
\hline \multirow[t]{2}{*}{ Rate of skill acquisition } & Literate trainees & 96 & 101.82 & 3.62 & & & \\
\hline & Illiterate trainees & 104 & 94.03 & 2.74 & 198 & 17.25 & $\mathrm{P}<.05$ \\
\hline
\end{tabular}

Table 6 indicates that there is a significant statistical difference between the rate of skill acquisition among trainees with different levels of literacy at $[\mathrm{t}(198)=17.25 ; \mathrm{P}<.05]$; hence the mean for literate trainees is $(\overline{\mathrm{X}}=101.82 ; \mathrm{SD}=3.62)$ and mean for illiterate trainees $(\bar{X}=94.03 ; \mathrm{SD}=2.74)$. This result shows that trainees with literacy had higher mean score on skill acquisition while those with no literacy had significantly lower mean score. Therefore, this above stated null hypothesis is rejected.

Hypothesis 3: There is no significant difference in the perception of trainers (both literate and illiterate ones) on the importance of literacy in vocational skill acquisition.

Table 7. T-test summary showing the perception of trainers on the importance of literacy among trainees

\begin{tabular}{|c|c|c|c|c|c|c|c|}
\hline & Literacy & $\mathrm{N}$ & Mean & S.D & $\mathrm{df}$ & $\mathrm{t}$ & Sig. \\
\hline & High & 90 & 26.82 & 3.62 & & & \\
\hline Skill acquisition & Low & 110 & 19.03 & 2.73 & 198 & 17.25 & $\mathrm{P}<.05$ \\
\hline
\end{tabular}

Table 7 revealed that trainers (both literates and illiterates) believed that literacy is important in skill acquisition at $[\mathrm{t}$ $(198)=17.25 ; \mathrm{p}<.05]$. This reveals that literacy is very important in skill acquisition as perceived by trainers. The tested hypothesis is thereby rejected.

\section{Discussion}

The main aim of vocational skill acquisition is to ensure self relevance and to ensure that individuals' standard of living within the community is improved and when this is done individuals within the community will participate effectively in community issues.

The study discovered that it is not only school drop-out or stark illiterates that engage in vocational skill acquisition .Because people have realized the fact that government cannot provide jobs for everybody, people who are highly educated also participate in vocational skill acquisition even through apprenticeship scheme. This is in line with the observation of Omoniyi and Osunde that the main aim of skill acquisition is to promote self - dependence and selfreliance in the generation of gainful self employment. They also believe that vocational skills prepare individuals for a more useful and fulfilling life within the society thereby being able to not only improve their standard of living but also able to participate effectively in community development issues.

It was discovered that being literate will provide efficiency in job performance and will help individuals to contribute positively to the growth of their communities and the notion at large. The importance of literacy is supported by the Nigerian government Policy and so provision is made hence the provision of a section for Mass Literacy, Adult and Non formal programmes in the Nigerian policy of education (FRN 2004).

It was also discovered that those with lower level of education also believe that literacy will facilitate better job performance as you will enable them to search for relevant information.Literacy will open people up to the world of information, thereby releasing them from the evils that have held them hostage for long. Jegede et al (2010) believed that literacy skills are fundamental to personal empowerment, participation in local, national and global issues. eventually will lead to development and that literacy is essential for the establishment of a sense of personal competence and autonomy.

The study discovered that although not all the master artisans were well educated, they all believed that literacy is an essential part of everyday living and that literate apprentices would perform better than illiterate ones. Some of them exceed confidence in what they are learning because of their literate abilities since they would get back home, read more and find out more about what they were exposed to practically in the world of books. This is supported by Bingman 2000, in Jegede et al (2010) that literacy helps people to develop self confidence to know and feel better about themselves and that literate persons exude greater self esteem than the illiterate ones in vocational skill acquisition and literate persons are able to give better voice to their convictions about issues than their illiterate counterparts. It was generally discovered that the impact of literacy in vocational skill acquisition cannot be over emphasized.

\section{Conclusion and Recommendations}

The study examined the impact of literacy on vocational skill acquisition and the discovery from the point of view of apprentices as well as those of trainees was that literacy is very essential in the course of skill acquisition and that it should be encouraged. 
There is no doubt that the Nigerian government is doing a lot to promote literacy among its citizenry, yet this government should still intensify its effort at making everybody literate.

Many more centres should be located in markets and other places to enable everyone have access to literacy education.

The literate apprentices should affect their illiterate counterparts positively by encouraging them to enroll at literacy centres and make them understand the impact of literacy in vocational skill acquisition.

Parents should encourage their children who have left school early to enroll at adult education centres so to become literate in order not to be left out in the scheme of things.

The illiterate apprentices should not exercise inferiority complex in the presence of the literate ones but make friends with them so as to more ahead and make progress.

The master artisan/trainers should grant their trainees time to attend literacy classes while they should also improve their literacy level so as to become effectively functional on the training of their apprentices.

\section{References}

Independent Commission in Population and Quality of Life( 1996). Caring for the future: Making the Next Decades Provide a Life Worth Living. Oxford, Oxford University Press.

Nnazor, R. (2005). Adult Education in Nigeria: The Consequence of neglect and agenda for action in International Education Journal 6(4) 530-536.

Oyitso, M. and Olomukoro C.O. (2010). Enhancing Women Development Through Literacy Education Programmes in Nigeria: A Paper presented at the( 2010). NNCAE National Conference Held in the University of Ibadan, 7-9 December 2010.

Women Watch (2005). Information and Resources in Gender Quality and Empowerment of Women. Education and Training Women and the Girl-Child Sponsored by UNESCO and UNICEF, 10 January - 4th February 2005 (moderated by UNESCO).

Okerulu, E.O. (2003). Digital Libraries: Creating a new vista in Library Services for the visually impaired in Nigeria.

Lagos, Journal of Library and Information Science 1(2) 152-155.

Julien, H. (2002). Use of Information Encyclopedia of Communication and Information. USA. Macmillan p. 1051 1056.

Abdulwahab, O.I.; Amusan, B. and Umma, D.D. (2009). Effects of Information Literacy Skills on the use of E-library

Resources among Students of the University of Ilorin, Kwara State; Nigeria. www.webpages.uidaho.edu/mbolin/issablessing-daura.html (1712/12).

Federal Republic of Nigeria (2004). National Policy on Education, Lagos, NERDC Press.

Faniwo D. and Oyedele, W. (2012). Impact of Skill Acquisition Entrepreneurship on National Development www.ngrguardianviews.com. Tuesday 27 November.

BRF Forum; Fashola Handover Mushin Skill. Acquisition and Vocational Centre http://www.brfforum-uk-uk.org/index (22-11-12).

Rogers, A. (2001). Some Contemporary Trends in Adult Literacy from an International Perspective. Adult EducationDevelopment Issue 56 pp. 21.

Omoruyi, F.E.O. and Osunde, A.U. Evaluating the Effectiveness of the National Youth Employment and Vocational Skill Acquisition Programme in Mid Western Nigeria: www.112-dvv.de/index/php (Accessed 21/12/12).

Jegede, O.I.; Ojo-Ajibare, J.O., Ememe, P.I. and Aitokhuehi, O.O. (2010). Literacy as a tool for Fostering Political Emancipation" A Paper Presented at the 2010 Conference of the Nigerian National Council of Adult Education (NNCAE 7- $9^{\text {th }}$ December, 2010, University of Ibadan, Nigeria. 